\title{
The new pharmacy market in Sweden
}

\section{Matts Balgård}

Over the past 4 years the pharmacy market in Sweden has been overhauled. What used to be a state monopoly has turned into one of the most liberal pharmacy market situations in Europe. The aim of this article is to give a brief overview of how this happened and what the situation is like today, with a focus on hospital pharmacy. I will also provide some comments on the current trends in Swedish hospital pharmacy.

In 1971 all pharmacies in Sweden were expropriated by law and amalgamated into one national pharmacy corporation owned by the state (Apoteksbolaget, later Apoteket AB). Apoteket AB's monopoly to sell pharmaceutical drugs to the general public remained until 2009. The hospital pharmacy market was legally never a monopoly, ${ }^{1}$ but in reality, Apoteket AB also ran all hospital pharmacies on a contract basis as there was no serious competition. In the general election of 2006 the Social Democratic Party lost power to a right wing coalition of four parties. One item on their political agenda was to break up the pharmacy monopoly. This was partly driven by the ideological belief that free market competition in general will provide improved availability and reduced prices, but also by EU pressure to dismantle state monopolies. The government appointed an inquiry in December 2006 to outline a liberalised pharmacy market in Sweden. ${ }^{2}$ The resulting official report formed the basis for the drastic legislative changes that followed, referred to as the re-regulation in this article. ${ }^{3-5}$

The re-regulation of the Swedish pharmacy market had three parts, all of which were implemented in parallel:

\section{Changing hospital pharmacy regulation to provide flexibility for caregivers to organise their drug supply as they see fit. ${ }^{3}$}

Correspondence to $\mathrm{M}$ Balgård, Department of Pharmacokinetics and Pharmacotherapy, Uppsala University, Uppsala 75124, Sweden; matts.balgard@farmbio.uu.se
2. The creation of an open market for community pharmacies by breaking up Apoteket $\mathrm{AB}$ and its monopoly. ${ }^{4}$

3. Opening up for most over the counter (OTC) drugs to be sold in general retail stores. ${ }^{5}$

The legislative framework for community pharmacy practice stipulates that prescribers and drug manufacturers are not allowed to directly own pharmacies. ${ }^{6}$ There is no requirement to be a pharmacist to own a pharmacy but there must be a pharmacist or prescriptionist (holder of a 3 year bachelor of pharmacy degree) responsible for its operation. A pharmacist/prescriptionist must also be present during opening hours. ${ }^{6}$ All pharmacies must be licensed by the Medicinal Products Agency (MPA) ${ }^{6}$ and they have an obligation to be able to dispense any licensed drug within $24 \mathrm{~h}$. 7 Prices for drugs included in the state subsidiary system are set by the Dental and Pharmaceutical Benefits Agency and reviewed monthly.

Apoteket $\mathrm{AB}$ consisted of approximately 880 community pharmacies and 75 hospital pharmacies before the re-regulation. Two thirds of the community pharmacies were sold to new pharmacy chains in eight clusters of varying sizes while the inpatient hospital pharmacy business was largely retained in a newly formed daughter company named Apoteket Farmaci AB. The new pharmacy market grew quickly. About 200 additional community pharmacies had opened in Sweden by the end of $2010 .^{8}$ This created a demand for community pharmacists and increased salaries in areas of the country where there was a shortage of skilled personnel, particularly for people who switched employer. ${ }^{9}$ However, during the second half of 2011 there have been signs of market saturation as some pharmacy chains have announced layoffs and closure of pharmacies in response to poor financial results. ${ }^{10-12}$

The fact that the top selling brands of OTC drugs are available in general retail stores and prices of prescription drugs are tightly regulated has diminished the earning potential of community pharmacies. ${ }^{8}$ Selling non-drug articles has therefore become a vital source of revenue, spurring pharmacy practice in a more commercial direction. ${ }^{13}$ Originally the government intended to explore models for reimbursement of pharmaceutical services but these plans have been abandoned. ${ }^{1415}$ Many pharmacists find it is unfortunate and worrying from a professional point of view that the main incentive of community pharmacy practice is limited to maximising non-drug business.

Despite the fact that the number of pharmacies as well as opening hours has increased after the re-regulation, public polls have suggested that the general public is less satisfied with the pharmacy service. ${ }^{16} 17$ This is attributable to uncommon drugs being less regularly kept in stock and pharmacies struggling to meet the 24 $\mathrm{h}$ dispensing time frame. ${ }^{1718}$ Another contributing factor is that all pharmacies shared the same computer system during Apoteket AB's monopoly, which made it possible to check stock levels of any given pharmacy. This appreciated feature is in most cases no longer available as pharmacies in a neighbourhood often belong to different retail chains. ${ }^{19}$ Drugs have not become notably cheaper overall and there has been a debate in the press about how pharmacy staff are perceived as less knowledgeable by the customers. ${ }^{17}$ On the positive side, the re-regulation has allowed pharmacy entrepreneurs to explore professional ideas and business models that would not have been given a chance to bloom under Apoteket AB's monopoly.

Turning to hospital pharmacy, new legislation in September 2008 radically changed organisation of the practice. Each caregiver is responsible by law for organising drug supply to and within its hospitals in such a way that the availability of safe and effective drugs is ensured. To this end there should be a hospital pharmacy staffed by at least one pharmacist or presciptionist. The caregiver must submit a description of how the hospital pharmacy is organised to the MPA. ${ }^{6}$ It is important to note that the definition of a hospital pharmacy in the legal context is any activity that is part of the drug supply system to or within a hospital. ${ }^{6}$ 
The legislation is intentionally vague and flexible to provide caregivers with freedom to organise their hospital pharmacy function as they see fit. ${ }^{20}$ There are for example no requirements to have a physical hospital pharmacy present at the hospital or to have the same provider for all hospital pharmacy service components. One interesting feature of the legislation is that hospital pharmacies run by the caregiver do not require a licence from the MPA as the function is considered part of the healthcare system. ${ }^{6}$ This exemption only pertains to inpatient services. A community pharmacy license is needed for outpatient pharmacy practice. $^{6}$

Healthcare in Sweden is predominantly public and financed by taxes. There are 20 county councils, including four regions responsible for hospital and primary healthcare in their respective geographic areas, while the 290 municipalities are responsible for care of the elderly. ${ }^{21}$ There are also private healthcare alternatives but these are minor providers in comparison with the public healthcare system.

Apoteket $\mathrm{AB}$ operated all hospital pharmacies on a contractual basis with each county council prior to the re-regulation in 2008..$^{22}$ The basic service typically comprised inpatient drug distribution and aseptic preparation of cytotoxics and extemporaneous parenteral compositions. Additional services were often included according to local requests and agreements-for example, clinical pharmacy, participation in drug formulary committees, drug education, drug use review support, etc. ${ }^{22}$ The scope of additional services varied between different county councils. The fact that Apoteket AB was the sole body that managed hospital pharmacies in Sweden led to a fairly standardised way of working, nationwide support systems and extensive professional networks within the company. Apoteket $\mathrm{AB}$ and its daughter company Apoteket Farmaci $A B$ were the driving force behind strategic development of hospital pharmacy practice.

Perhaps the most striking effect of the new hospital pharmacy legislation is that the county councils have taken over this strategic role. The legal obligation to organise a hospital pharmacy has awakened a sincere interest in pharmaceutical matters and pushed the county councils to build up pharmaceutical competence within their own organisations. ${ }^{23}$ Today, the county councils in Sweden directly employ more than 150 pharmacists, which corresponds to a fivefold increase over the past few years. ${ }^{24}$ Many of those employed are senior hospital pharmacists recruited from Apoteket Farmaci AB. There is a clear trend that qualified pharmaceutical services are taken over and incorporated into the organisational framework of the county councils while drug distribution and extemporaneous preparation are outsourced by public procurement when the current contracts with Apoteket Farmaci expire. ${ }^{2324}$

The tender specifications for the hospital pharmacy procurement processes that have taken place so far have been very diverse. Some county councils have requested the winning contractor to provide a complete hospital pharmacy service while others have split the service components into different tenders. As an example, the procurement for Region Skåne, in the south of Sweden, consisted of three tenders: one for aseptic preparation, one for wholesale drug distribution to all hospitals in the region and one for managing the ward stocks at each respective hospital. Apoteket Farmaci won the tenders for preparation and drug distribution while a novel hospital pharmacy enterprise named Vårdapoteket won the ward stock tender. ${ }^{25}$ Thus one contractor delivers drugs to the hospitals where another picks them up and restocks the wards. Meanwhile, Region Skåne's own pharmacists provide the clinical pharmacy services. ${ }^{24}$ Naturally a solution like this requires clear responsibilities and smooth processes in order to avoid drug shortages or misunderstandings that could potentially jeopardise patient safety.

Over time both healthcare providers and hospital pharmacy contractors will gain experience with this new way of working and standardised practice models will inevitably emerge.

Overall the new hospital pharmacy legislation has diversified practice. An advantage of the new system is that hospital pharmacy has become more closely knit into the healthcare system as caregivers adopt responsibility. ${ }^{24}$ Clinical pharmacy in particular has benefitted from this change as it is the advantage for the pharmacist of belonging to the same organisation as the rest of the multidisciplinary healthcare team. The fact that the pharmacist used to be an external consultant sometimes complicated collaboration. Most county councils now have clinical pharmacists employed and patient centred pharmaceutical care is growing.

A negative consequence of the new situation is that the unified national framework for hospital pharmacy provided by Apoteket Farmaci AB is lost. ${ }^{24}$ Hospital pharmacists in different areas who are

\section{Key messages}

New legislation has liberalised the pharmacy market in Sweden. New community pharmacy chains have emerged and practice has become more commercial. OTC drugs are sold in general retail stores. The definition of a hospital pharmacy is flexible and caregivers are responsible for organising it as they see fit. There is a trend that qualified pharmaceutical services are incorporated into the organisational framework of the caregivers while drug distribution and aseptic preparation services are outsourced by public procurement.

working with similar issues are forming new networks but the same central support structure is no longer available. Practitioners are more on their own to find peers, develop standards and maintain continuing professional development. ${ }^{24}$ The author, along with other hospital pharmacists, also sees a risk that the characteristic competence profile of the profession is weakened by the fragmentation of service components in a longer perspective. Hospital pharmacists tend to be involved in many areas fostering a broad expertise on inpatient drug matters. This general overarching understanding of drug use and drug supply is potentially compromised when core service components become separated through procurement and reorganisation.

For the hospital pharmacy companies, business has become very tender driven since the re-regulation. They are forced to adapt to rapidly changing market premises and customer demands. Individual hospital pharmacists have the option to work for a variety of employers although the effect on salaries has been less evident than in community pharmacy.

The current changes in hospital pharmacy practice are ongoing processes that have not yet settled into a matured form. The legislative framework is intentionally broad and flexible but it has become evident that there is a need for some amending and clarification. The MPA has recently invited public feedback on a draft regulation that establishes minimum quality requirements for hospital pharmacy practice. This is a welcome initiative as the only legal guidance currently available is that the hospital pharmacy should ensure that inpatient drug supply is safe and effective. A tighter regulation or an accreditation system is warranted. This is an area for the professional bodies and the MPA to address. It is a very important topic for the Swedish Association for Pharmaceutical Sciences' section for hospital pharmacy to work with in the coming years. 
Acknowledgements The author would like to acknowledge the board of the Swedish Association for Pharmaceutical Sciences' section for hospital pharmacy for input on this article.

Provenance and peer review Commissioned; externally peer reviewed.

\section{References}

1. Kungörelse (1970:738) om läkemedelsförsörjningen vid sjukvårdsinrättningarna. Available from: http://www.notisum.se/rnp/sls/lag/19700738. HTM (in Swedish) (accessed 24 Jan 2012).

2. Department of Health and Welfare press release 21 Dec 2006 (Internet). Regeringen.se [cited 2011 Dec 27]. Available from: http://www.regeringen. $\mathrm{se} / \mathrm{sb} / \mathrm{d} / 8090 / \mathrm{a} / 74378$ (in Swedish) (accessed 24 Jan 2012).

3. Reje L. Sjukhusens läkemedelsförsörjning. SOU 2007:53. Available from: http://www.regeringen.se/content/1/c6/08/66/12/6773a1a5.pdf (in Swedish) (accessed 24 Jan 2012).

4. Reje L. Omreglering av apoteksmarknaden. SOU 2008:4. Available from: http://www. regeringen.se/content/1/c6/09/54/10/2a0484f5. pdf (in Swedish) (accessed 24 Jan 2012). Available from: http://www.regeringen. se/content/1/c6/09/54/10/c43e5833.pdf (in Swedish) . http://www.regeringen.se/content/1/ c6/09/54/10/728f4e24.pdf (in English) (accessed 24 Jan 2012).

5. Reje L. Detaljhandel med vissa receptfria läkemedel. SOU 2008:33. Available from: http://www.regeringen.se/content/1/ c6/10/19/19/3685dbcb.pdf (in Swedish) (accessed 24 Jan 2012).

6. Sales of medicinal products act (SFS 2009:366) Available from: http://www.notisum.se/rnp/sls/ lag/20090366.htm (in Swedish) (accessed 24 Jan 2012)

7. Sales of medicinal products regulation (SFS 2009:659). Available from: http:/www.notisum.se/ Pub/Doc.aspx?url=/rnp/sls/lag/20090659.htm (in Swedish) (accessed 24 Jan 2012)

8. The Swedish Pharmacy Association's yearly report 2010. Available from: http://www. sverigesapoteksforening.se/wp-content/uploads/ AFP-Branschrapport.110504.pdf (in Swedish) (accessed 24 Jan 2012).

9. Bergeå Nygren N. Löneklipp med nytt apoteksjobb. Svensk Farmaci 2011;1:12-13.

10. Olow A, Bergeå Nygren N. Ostadigt nybyggemånga förklaringar till dålig start för kedjor. Svensk Farmaci 2011;6:7.

11. Begeå Nygren N. Nedläggningar spås bli del av vardagen-turbulent apoteksmarknad att vänta. Svensk Farmaci 2011;6:4-5.

12. Hed F. Tuffare tider för apotekskedjorna. Läkemedelsvärlden 2011;8:11.

13. Bergeå Nygren N. Backlash? Svensk Farmaci 2011:5:11-14.

14. Farmaceviska tjänster utreds inte. Läkemedelsvärlden 2011:1:13

15. Langseth A. Strid om statliga hälsopengar Oenighet om apotekens vårdnära tjänster ska subventioneras eller inte. Svensk Farmaci 2011;4:20-1.

16. Parmler J. Detaljhandeln enligt Svenskt Kvalitetsindex 2011 (Internet). Kvalitetsindex.se [cited 27 Dec 2011] Available from: http://www. kvalitetsindex.se/images/stories/Results/2010/ SKI_om_detaljhandeln_11.pdf (in Swedish) (accessed 24 Jan 2012).

17. Berglund CM, Hall H. Omregleringen av apoteksmarknaden-Redovisning av ett regeringsuppdrag. Konsumentverket rapport 2011:9. Available from: http://www. konsumentverket.se/Global/Konsumentverket. se/Beställa\%20och\%20ladda\%20ner/ rapporter/2011/2011 9 omregleringen av apoteksmarknaden.pdf (in Swedish) (accessed 24 Jan 2012).

18. Nilsson I. 24 timmar ställer till problem. Läkemedelsvärlden 2011;3:11.

19. Hernadi A. Läkemedelstillgänglighet kritiseras. Svenska Dagbladet (Internet), 2010, Mar 3 [cited 2011 Dec 27]. Available from: http://www. svd.se/nyheter/inrikes/lakemedelstillganglighetkritiseras_4366791.svd (in Swedish) (accessed 24 Jan 2012).

20. Government Bill 2007/08:142. Sjukhusens läkemedelsförsörjning (Prop. 2007/08:142). Available from: http://regeringen.se/content/1/ c6/10/39/34/2d0d1057.pdf (in Swedish) (accessed 24 Jan 2012).

21. The Swedish Association of Local Authorities and Regions. Levels of local democracy in Sweden. Ljungbergs tryckeri. ISBN 978-91-7164635-4. Available from: http://brs.skl.se/brsbibl/ kata_documents/doc39893_1.pdf (in English) (accessed 24 Jan 2012).

22. Apoteket AB Annual report 2008. Available from: http://www.apoteket.se/privatpersoner/ om/Documents/Om\%20Apoteket/Finansiell\%20 Info/Apoteket\%20Eng_bookmark-locked.pdf (in English) (accessed 24 Jan 2012).

23. Nilsson I. Förvirrat inför upphandlingen. Läkemedelsvärlden 2010;1:34-5.

24. Bergeå Nygren N. Apotekare landar i landstingsvärlden-Farmacin blir en allt mer integrerad del av den svenska vården. Svensk Farmaci 2011;1:4-6.

25. Region Skåne press release 2010 Nov 23 (Internet) [cited 2011 Dec 27]. Available from: http://www.skane.se/sv/Nyheter/Regionledning/ Arkiv/Upphandling-av-lakemedelstjanster-gerbesparing-pa-38-miljoner/(in Swedish) (accessed 24 Jan 2012) 